\title{
A Sombra da Caça
}

Embaçados os meus olhos pela névoa e a poeira do vidro, sinto o peito apertar, e sempre me restam códeas de pão e o leite, a que acrescento água, antes que termine. Choro só pela manhã, os olhos filtram a luz que me socorre. E lamento a tua ausência. Que nem o trem e o avião me trazem de volta, apenas tuas cartas me chegam, sempre perfumadas, como tradição familiar. Sei que você me quer, sempre diz querida mãe, e acho que me comovo. Mas, me pergunto, por que não voltas ao menos uma vez a casa, para chorarmos juntos. Bastaria cruzar a porta para reconhecer os objetos da sala, os mesmos móveis de quando teu pai sucumbiu afinal às coisas terrenas. A princípio ele se sentia aviltado com as cadeiras, a mesa, $o$ armário. Para depois usufrui-los como desejando que nos fizessem companhia até a velhice. Passou a arrastar os móveis pela casa embelezando-os. Pediu que eu o ajudasse. Fingi não ver seus gestos, combatia-lhe a afetividade exagerada, que nos inclinava ao fausto. Ameaçava-o com olhar e faca, descascando laranjas ele queria a casca no chão para amargurar-me a vida. Ele sorriu sempre, mesmo com a vida numa caixa de ferramentas. Você se lembra? Passo às vezes os dedos na beirada da cama, teu pai e eu ali dormíamos esquecendo de apagar a luz, e onde vocês nasceram. Não fomos raça andarilha. Alguma vez pastor, sim, logo que os animais queriam o prado, nós os forçávamos ao repouso. Até que nos estabelecemos debaixo das árvores e aqui estou, tudo leva meu nome, pois agora minha memória é o esquecimento. Esquecer é repetir as mesmas palavras, a ciência de batizar sem esperança, e ficar mais pobre. Identifico assim o mundo que me restou. Em teu nome, dos mortos, e de teu pai. Conservo como lembrança, bem dentro do lenço que arrasto para perto do coração, o dia do teu nascimento, aquele instante de renovação e dor. Quando as paredes começaram a descascar, eu insistia para o pai ao menos uma vez esquecer o mundo e devotar-se às pompas que eu urgia, de que outro modo eu poderia ficar dentro de casa e sonhar. Prometeu trabalhar na semana seguinte, rasparia as paredes, a brocha em cima haveria de iluminar a casa de branco. Eu duvidava da palavra que se dizia de rei, sempre duvidei da claridade que ele 
jogava sobre a mesa junto ao pão. Aquela semana se desvaneceria do calendário. E onde estou, filho, que o tempo me substitui? Embalava você no colo, o pensamento voltado para tua pele de seda. Pela carícia o dedo como que murchava, só o brilho de tua pele de filho me empolgava. Pedi ao homem que vivesse comigo a mesma aventura. Ele te beijou, cheirava como tragando fumo, dizia o cheiro é a fonte da vida. Suas palavras me venciam, bastava eu descobrir o pêssego para ele comê-lo com a perfeição que me afastava do amor. Não podia deliciar-me com seu rosto em fogo, a coragem dele possuir em frangalhos o próprio corpo. Ofendi-lhe o nome, constitui ladainha em que conjurava seus defeitos, cobria-o de martírio e ridículo, diariamente atirando-lhe dardos e setas, que ele fingiu jamais contar. Era amável, que amabilidade meu deus é esta que fazia florescer minha aspereza. Seja rude, pedi-lhe, ele me depositou flores apenas amanhecendo. Eu gritei, ele me deu as costas, voltando logo como quem não sabe brigar, inventava onde deixei os cigarros. Na volúpia da ofensa não o deixava recordar que havia abandonado os cigarros à minha frente. Jamais o socorri no gesto que se transformasse em prazer. Ele saberia ser feliz sem mim. Uma salvação solitária e eu não perdoava. Teve sempre condições de armar fogueira sem fósforo, vinha-lhe pelo assovio o pássaro em linha reta, desistindo do vôo. $O$ fazer-se amado sem falar o tanto que eu consumia diariamente. Para castigá-lo, aboli as virtudes, exagerava a sorte que naquela casa ia diretamente para ele. Mesmo com a camisa rasgada o rubor de sua face o enaltecia. Não tem vergonha de ser feliz quando eu não sou, disse-lhe desconsolada. Passou a mão pelo meu cabelo, foi o único tesouro de minha família, ele explicou, não fiz outra coisa que te oferecer a chave desta mesma felicidade. Nunca me pareceu ele tão bonito. Eu me via feia, corrompia-me o sal que tragava puro sem auxílio de água. Não adiantam o perfume, batom, carmesim de feira, ou você transportando fios de seda com que me amarrar em os pés, disse-lhe, para ele desistir de palavras gratas, com destino de arruinar-me. Sentindo-se culpado, ele zelava por aquela amarga corrente de vida que ainda me deixava andar. Fui à horta, custei a regressar. Neguei-lhe o prazer de salvar-me no momento difícil, eu já nãoo amava, permitira que o amor de longínqua era se convertesse em sentimento cobrando aspereza, espinho, madrugadas. Ele me deixava bilhetes, eu os rasgava sem ler. Você ainda me mata com um arrebato que não tenho condições de absorver, disse-lhe quando me olhou querendo resposta urgente para a última mensagem. Você, meu filho, fora o último a nos bater à porta. Mal podia compreender a desavença que eu propunha ao pai. Cheguei a gritar para você, que crescia e me largava solitária, então, até você, como os outros, não reconhece a dívida que eu faço questão que se pague? O homem pedia, por que a dívida, por que o dinheiro, e para que o caminho certo? E por responsabilidade e a certeza do futuro, expliquei-lhe, transtornada pela chuva. Ele disse eu te amei sem sonhar que o nosso amor um dia acabasse, e pude ouvir-lhe o pulsar delicado do coração, como se o tivesse amarrado aos dentes. Neguei-lhe o estremecer de seu corpo que ia a agonia pela minha vida perguntando não terminas jamais de ter fome, e lá 
vou eu para a cozinha desfazer-me dos restos do teu prato? Surpreendi a lágrima pelo seu rosto. Senti a pujança do triunfo, ofendia-o como necessitava para guardar-lhe o rosto crispado de lembrança, un bilhete esgarçando-se pelos anos de manuseio. Olhamo-nos longamente, não podia ele compreender que eu precisava derrubá-lo para manter a integridade do lar. Não nos deixe, eu lhe pedi, esta é a única chave da felicidade para mim. Pediu-me explicações, que felicidade é esta que corrompe metais, sem antes deixá-los fulgurantes? Tomei da única prata da casa, passei creme, esfreguei-lhe com a fartura de meus dedos, exibindo-lhe obrilho afinal. Não adianta, mulher, eu já parti há muito tempo, mas você não percebeu. Preparei-lhe farta merenda, com precisas indicações para abandonar a casa, também eu o considerava estranho, não o queria na mesma cidade que a sorte nos unira. Ele beijou os filhos diante de mim, você foi o último, por muito tempo acariciou-lhe os cabelos, talvez seja melhor assim, disse, era passageiro de um bonde que nos leva até onde se sente a emoção que a jugular rasgada por um olhar de amor nos deixa, apesar da felicidade. Meu deus, um único olhar seu ao menos, eu o havia amado por toda a vida, ele foi um fragmento de pele que me roçou e desfaleci porque a vida sangrava diariamente. Eu precisava desfazer os nós do arame farpado sob o impulso do dilaceramento, filho, porque nunca amei tanto o pai como no momento que o perdi. Meu corpo crivado de volúpia, ouriço, e a mania de perseguirThe a sombra através de todos corpos que me chegassem perto. A respiração do homem guardo num envelope, compassada e triste. Jamais selei este envelope, não sei a quem remeter o tormento que só a mim me diz respeito. Não posso explicar porque fui seduzida pela dor. Eu estava carente de sofrer, mais que de amar. $\mathrm{O}$ amor me comprometia e me exilava do mundo. E eu almejava a porção contaminada pelo veneno da terra. Ah, filho, porque te descrevo os meus mistérios, os sonhos do pai, que nem sei mais onde vive, ou se já morreu. Mesmo quando o envelheço e traço-lhe um retrato atual, que eu própria não estive próxima para amarelar, e sei que outras mãos afundaram-se em seu corpo, sinto o despeito retocando minhas vísceras, aperfeiçoando-lhes a beleza. Nesta vigília então de sombras e intestinos eu me faço bela, vejo meu sexo a pedra de uma terra em abandono. Que vergonha, filho, como ouso alimentar-te com os vestígios de semelhante paixão, se mal te nutri de leite, ignoro mesmo se você é homem para suportar os encargos de um rosto atado com feixes e nervos. Ele cruzou a porta olhando para trás uma única vez, disse, a porta é a moldura, sabia? e riu delicado, como era capaz na hora de sufocar-me de água que eu não poderia lamber no chão. Se tivesse me agarrado às suas pernas, arrancadolhe os cabelos, proclamando aceito a tua chave enferrujada de tanto salitre, convívio humano, o abuso do teu sorriso, mas seja meu, fique no ninho de cactus, conchas e andorinha, ele teria ficado comigo. Nem ao menos sorri, para assegurar-se ele de um direito que lhe teria permitido regressar quando ficasse doente. Ah, meu filho, me atormenta imaginá-lo em alguma parte da terra assinalando um trem já indo longe, em cuja janela reconheceu um amigo. Acaso ainda posso pleitear tal amor, que se destruiu com o mesmo 
afinco com que se levanta a parede de uma casa? Olho o carteiro todos os dias, ele me saúda pressentindo que seu gesto me ampara a viver. Todas as cartas me equivocam, as suas, dos outros filhos, os cheques que me mandam sempre. Só o homem desistiu de enviar os rascunhos trancados na gaveta da cômoda. Para quem agora assinará os bilhetes da sua perdição? Ou como lava as camisas que se esgarçavam pela ausência de ambição, sua incapacidade de substituí-las por outras forradas de ouro. Temeu sempre que junto ao ouro lhe chegassem suspiros, murmúrios, a imensa tristeza. Me dizia, uma dia ainda nos entenderemos. Eu lhe prometia, mas que compreensão quer de mim se me foi dado apenas enxergar-te pela metade, minha visão se amesquinha dividindo uma laranja em duas partes, uma vai para a retina, a outra para onde não sei e padeço. Ele se apiedava, quando lhe vinha a paciência em golfadas, alisava-me o cabelo, oferecia-me uma xícara de chá. Ah, o vapor das xícaras que me trazia para saciar a intriga. Eu deixava esfriar para reduzi-lo no infinito. Percebendo a rede de peixes que lhe tecia eu em torno desfazia-a com palavras juvenis, você é bela, pelo teu corpo aspiro o cheiro do pinheiro. Fugaz eu me deixava arrebatar, logo afugentando uma generosidade que se cravava no meu corpo como dor. Ele pediu quer ir ao rio comigo, verá que hei de errar a serviço da natureza. Aceitei o convite orgulhosa do seu prometido fracasso. Nos despojamos de ornamentos, a comida ficou em casa. Mas com barbante apenas mergulhado no rio ele recolheu maravilhas, peixes vivos, folhas douradas e pedregulhos escavados pela lentidão de duzentos anos. Chega, gritei, foi para humilhar-me que me trouxe de longe, do abrigo da casa? Eu quis apenas te homenagear, ele se desculpou e nos repelimos até o escurecer. Para voltar, recusei a firmeza de suas mãos. Não deixei que me tocasse nesta noite, e nas outras eu me dava fria como os pedregulhos do rio que alguns guardei no bolso. Ele não reclamava, consentia meu corpo esfriando ao sol. Para exibir-lhe uma alegria que também eu poderia exportar para o oriente, ofereci-lhe meu corpo, a prova do seu permanente fracasso. Mas ele de repente não quis. Antes a escuridão, e repeliu a fonte de água mineral, sugos, musgos, os jorros incessantes entre minhas pernas. Venha, assuma $o$ seu destino, falei imperiosa para tragar-me com uma fome que estava em mim, ele que tinha o dever de alimentar-me sempre. Não quero o corpo, ele insistiu. Eu o derrubei com a colher de bolo, obriguei-o a ficar na cama, disse se não me amar derrotado jamais me possuirá em qualquer momento de glória. Veio sobre o meu corpo, coberto de escamas que me arranhavam, raspavam os pelos, vi-lhe as guelras vermelhas, por ali sua respiração esfriava, sua boca cuspia água do mar, salgada, purgando pérolas deterioradas e algas que eu devia tragar para viver. Pela primeira vez me amou como um peixe. Não foi como urso. Peixe das funduras do mar, cego pela luz da minha vitória, nadando no meu ventre, vinha e se deixava roubar, eu pedia fique, fique para sempre, o peixe buscava água insuficiente no meu barril de amor e raiva, não havia salvação para aquela espécie que recusava o meu espasmo. Quando tombou ao lado, não era peixe, sobravam as escamas pelo lençol, madrepérolas me pareceram, Não me regalou com a 
aparência de animal que me fosse fácil amar. Podia ter sido por instantes a galinha ovo por.dentro, e a gente aninhada entre a clara, a gema e a escama apodrecendo devagar. Ah, meu filho, estou perdendo o bem da decência, permito-me confissões que não te trarão mais de volta a casa. Você há de evitar o meu olhar. Perdoe-me, não sei a quem dirigir para falar de um amor que nunca existiu, eu o combato até hoje com as unhas do relógio que me vigia noite e dia. Sei tão pouco de você, ignoro se o seu perdão é onda de mar, vem e volta. Nada sei de você, menos ainda dos objetos que me cercam. Que pena que o coração me dói e já vou me despedindo. Te quero com um querer pálido próximo ao querer que me ilumina em torno do retrato de teu pai. O homem me deixou, mas eu o derrotei também. Te abençôo, começou a chover.

Um bilhete rápido, mãe. $O$ pai também te amou. Com a decisão de te matar, embora o mesmo amor o fizesse atar pelas manhãs as patas que te encharcariam de veneno. $E$ te ia salvando no sorriso, no regalo de folhas secas e chá escaldando. Só quando ele morria quis revelar-me o segredo que o unia a você, desde o nascimento, assegurou-me ele. Você era a sombra e o sol. E por que não volta, pedi-lhe para levar em conta a solidão em que tu vivias, talvez sonhando com ele entrando porta a dentro. Disse apenas, há muito soltamos os animais no pasto, não resta umúnico sonho que colher como magnólia. Toquei-lhe a mão e disse: pai, a quem saio para também abandonar as casas que me abrigaram algumas horas? Ele disse: a mãe e eu deixamos instruções aos herdeiros para que se encaminhassem para a morte com orgulho e o dente altivo do javali. Foi o que ele fez, mãe. Morreu como se estivesse nascendo. $O$ que talvez te sirva de aviso que também começaste a morrer. Fez-me crer, isto sim, que te amou enquanto restava a vida. Agora não sei se ainda te ama, onde quer que esteja. Se está vivo na morte, ou pela força do teu coração saudoso. Do filho que te quer.

Rio de Janeiro

NÉLIDA PIÑÓN 
